\title{
"ALLEEN EEN GOD KAN ONS REDDEN"
}

\author{
Dirk De Schutter
}

\begin{abstract}
"Alleen een god kan ons redden". Mijn tekst ontleent zijn titel aan het interview met Martin Heidegger dat het Duitse magazine Der Spiegel in mei 1976 publiceert. Het interview heeft plaatsgevonden in september 1966. De onmiddellijke aanleiding ertoe is een in Duitsland aan de gang zijnde hetze over het politieke verleden van Heidegger en diens engagement als rector van de universiteit van Freiburg in het vervloekte jaar 1933. Heidegger heeft Der Spiegel zelf uitgenodigd voor een gesprek, en het is ook op zijn verzoek pas na zijn dood gepubliceerd. Tijdens dit gesprek valt de raadselachtige uitspraak: "Nur noch ein Gott kann uns retten." Des te raadselachtig is deze uitspraak, die testamentaire afmetingen gekregen heeft, omdat ze diametraal lijkt in te gaan tegen alles wat Heidegger ooit geleerd heeft. Immers, Heidegger heeft zich zijn hele leven lang afgezet tegen een "christelijke filosofie"; meer nog: zijn hele denken staat in het teken van een ontmanteling van de westerse filosofie, die -zoals hij zelf uitvoerig heeft aangetoond- doordrongen is van het christelijk gedachtegoed en van een door het christendom geïnspireerde theologie. Deze ontmanteling mondt bij Heidegger uit in een onvoorwaardelijke affirmatie van Nietzsches stelling over de dood van God.

Met deze gegevens als vertrekpunt wil ik in wat volgt Heideggers uitspraak ondervragen: Wie is de god die ons kan redden? Wie zijn wij en waarom hebben we nood aan een redding? Over welke soort redding gaat het hier? Maar eerst wil ik omstandig ingaan op Nietzsches boodschap over de dood van God en onderzoeken welke betekenis die toegemeten krijgt in Heideggers ontmanteling van de westerse metafysica.
\end{abstract}

Heideggers meest fundamentele kritiek luidt dat de westerse metafysica door een onto-theologische structuur getekend is. Zoals het woord zelf duidelijk maakt, wil Heidegger de aandacht vestigen op het merkwaardige samengaan van ontologie en theologie, of van de vraag naar het zijnde als zijnde en de vraag naar God. De vraag naar wat het betekent te zijn slaat om in de vraag naar het hoogste zijnde. Dit is al het geval in de metafysica van Aristoteles, bereikt een hoogtepunt in het theologisch systeem van Thomas van Aquino en deint uit in de theodicee van Leibniz en de process philosophy van Whitehead. God wordt de naam voor het culminatiepunt van een ontologisch onderzoek: hij is het opperste zijnde, dat noodzakelijk bestaat 
als volledige aanwezigheid, omdat hij de onlosmakelijke verbinding is van essentie en existentie. God wordt dus de naam voor de oplossing van vele moeilijkheden waarmee de ontologie te kampen heeft: de verhouding tussen essentie en existentie, tussen aanwezigheid en afwezigheid, tussen mogelijkheid en werkelijkheid, tussen noodzakelijkheid en contingentie.

Zoals gezegd, vertonen zowel de Griekse als de middeleeuwse filosofie dezelfde onto-theologische structuur. Dit verklaart meteen waarom de middeleeuwse filosofie, die als fides quaerens intellectum een rationele uiteenzetting van het christelijk geloof wil bieden, de inzichten uit de Griekse zijnsleer, en vooral uit de metafysica van Aristoteles, kan overnemen. Beide gaan ervan uit dat de wereld gemaakt of vervaardigd is. De middeleeuwse filosofie houdt vast aan het in Genesis verwoorde geloof dat God de wereld geschapen heeft uit het niets, en ook de Griekse filosofie is ervan overtuigd dat de kosmos door een samenspel van oorzaken tot stand gekomen is. Daarom heeft Aristoteles' leer van de vier oorzaken zich zonder veel moeite kunnen overplanten op de bijbelse scheppingsleer. De idee dat alles veroorzaakt is of dat niets zonder oorzaak gebeurt, heeft zijn definitief beslag gekregen in de hedendaagse technologie, die leeft van de manipuleerbaarheid en produceerbaarheid van al wat is en de totalitaire ideologie verkondigt dat zelfs de menselijke geschiedenis maakbaar is.

De stelling dat God aan de oorsprong ligt van alles wat zich voordoet, leidt op haar beurt naar het geloof in de totale inzichtelijkheid of intelligibiliteit van het geheel der zijnden. Hoewel de metafysica dient toe te geven dat veel verborgen blijft voor het beperkte menselijke bevattingsvermogen, betoogt ze tegelijk dat God alles weet en doorziet, omdat hij de totale keten van oorzaken en effecten die de gebeurtenissen sinds het begin der tijden stuurt, kan overzien. Deze redenering hangt af van de louter speculatieve idee dat de keten van oorzaken en gevolgen dan wel een oneindig lange reeks mag vormen, maar dat ze toch op een of andere manier kan worden getotaliseerd: het waarachtig oneindige, aldus Hegel, draagt zijn einde in zich en verwerkelijkt zich als een afgesloten geheel. De volledige inzichtelijkheid van al wat is, vormt ongetwijfeld één van de machtige steunpilaren van wat Derrida in het spoor van Heidegger de metafysica van de aanwezigheid genoemd heeft: alles wat is, kan uiteindelijk aanwezig gesteld of gepresenteerd worden; de instantie aan wie alles in de tegenwoordigheid verschijnt, is God. Zijn alwetendheid is rechtevenredig met zijn almacht. 
Omdat alles door God veroorzaakt is, leven we uiteindelijk in de beste van alle mogelijke werelden. God wordt weliswaar voor het tribunaal van de menselijke rede gedaagd om zich te verantwoorden voor het kwaad dat de wereld teistert, maar de uitkomst van dit proces is een vrijspraak: God treft geen schuld, het kwaad hangt wezenlijk samen met het vermogen van de mens om te kiezen en doet geen afbreuk aan de uiteindelijke deugdelijkheid van de schepping. De middeleeuwse filosofie vat het als volgt samen: "ens et verum et bonum convertuntur", dat wil zeggen: het zijnde en het ware en het goede zijn verwisselbaar. Hier wordt het geloof uitgesproken dat het goede uiteindelijk zegeviert, maar ook dat de schepping zich leent voor rechtvaardige ingrepen. De doeltreffendheid van het goede staat buiten kijf: de wereld is zo geschapen dat de gebreken ervan kunnen worden opgeheven. De alledaagse ervaring van de mens staat uiteraard haaks op deze bewering: niemand kan lichtzinnig voorbijgaan aan de alomtegenwoordigheid van het kwaad in de wereld, aan de onbegrijpelijkheid van het fysieke lijden, aan de onvergeeflijkheid van een naar het diabolische neigende slechtheid. Ook de filosofie kan deze ervaring niet loochenen, en toch heeft ze een middel gevonden om de pijn van deze ervaring uit de weg te gaan. Dit middel heet de twee-werelden-leer. De filosofie erkent dan dat vele mensen hier op aarde door een afschuwelijk noodlot getroffen worden, maar ze wijst er tegelijk op dat dit leven niet het echte is. Het noodlot verandert dan in een beproeving: de mens moet dit noodlot doorstaan om toegang te krijgen tot een andere, betere wereld. Het behoeft niet veel uitleg om te begrijpen dat het cynisme van deze redenering eindeloos kan worden uitgewerkt: alleen wie mateloos lijdt, alleen wie aan een hemeltergende onrechtvaardigheid tenondergaat, verdient de liefde van God, komt in aanmerking voor Gods goedertierenheid. Dit soms door de kerk gehanteerde dolorisme is niet teruggedeinsd voor witwasoperaties die de meest wraakroepende ellende verschonen of heeft zich beroepen op een slavenmoraal die de nutteloosheid en vergeefsheid der naastenliefde omzet in hemelse beloningen. De twee-werelden-leer, die hieraan ten grondslag ligt, doortrekt het hele filosofische systeem en genereert de hiërarchisch geordende tegenstellingen die het systeem aaneensmeden: de tegenstellingen tussen aarde en hemel, tussen lichaam en ziel, stof en vorm, zinnelijk en bovenzinnelijk, materieel en spiritueel zijn zo gerangschikt dat het eerste lid (de aarde, het lichaam, enzovoort) altijd opnieuw geofferd wordt ten voordele van het tweede (het bovenzinnelijke, het spirituele). Dit offer bewerkt de zinvolheid van het morele handelen in de door zinloosheid bedreigde schepping. 
In deze twee-werelden-leer herkent Heidegger, in navolging van Nietzsche, de wezenlijk nihilistische structuur van de westerse filosofie en theologie. Dit nihilisme komt niet alleen tot uiting in de verwerping van het aardse, het lichamelijke, enzovoort, maar vooral in de radicale loochening van de eindigheid. Inderdaad, Heidegger beklemtoont telkens weer dat het nihilisme niet schuilt in de stelling of het gevoel dat de werkelijkheid geen waarde heeft, maar wel in het onvermogen om een verhouding met de eindigheid aan te gaan. Het nihilisme ontkent het niets of nihil dat als een scheur het geheel der zijnden doorstreept. De metafysica van de aanwezigheid is nihilistisch, precies omdat ze elke vorm van afwezigheid bedingt, dat wil zeggen als voorwaardelijk aanziet: het sterven wordt gereduceerd tot een inleiding op het leven, de negatie tot een voorbode van de identiteit, de schijn tot het eerste stadium van de waarheid. Hoewel het christendom zich voordoet als een religie die aandacht heeft voor lijden en dood, omdat ze de menswording van God belijdt, kunnen we niet om de vaststelling heen dat veel menselijks Jezus, die de Mensenzoon genoemd wordt, vreemd is: hij wordt geboren uit een maagd, het is niet zeker of hij ooit gelachen heeft, zijn dood is slechts de overgang naar een verrijzenis en een hemelvaart. De opmerking dat die hele geschiedenis symbolisch moet worden geduid, doet nauwelijks ter zake. Immers, het blijft moeilijk om zich van de indruk te ontdoen dat de absurditeit van het sterfelijke lichaam hier met geweld wordt verdonkeremaand. Wat moeten we denken van een godsdienst die weliswaar de goddelijkheid van de geboorte viert, het gekwetste lichaam aanbidt en de eenzaamheid van de dood gedenkt, maar tegelijk de gepassioneerde onzinnigheid van het geslachtelijke en de lach loochent en de onmogelijkheid van de rouw banaliseert?

Het nihilisme dat in het christendom schuilt, komt het duidelijkst naar voor in de leer van de creatio ex nihilo en van de goddelijke triniteit. Eigenlijk heeft de christelijke theologie zich nauwelijks raad geweten met de idee dat God de wereld uit het niets geschapen heeft. Met uitzondering van onder meer Duns Scotus, de mystici en Schelling heeft de filosofie verzuimd om na te denken over de verhouding tussen God en het niets. Ze heeft de gedachte dat Gods schepping in het niets rust en contingent is, dat ze met andere woorden niet getekend is door noodzaak en dat ze anders had kunnen zijn, ontweken. Toch kan alleen een radicale affirmatie van deze contingentie de weg openen naar de mogelijke ervaring van liefde en generositeit, die aan God toegeschreven worden. Waarom heeft de filosofie zo vaak God gezocht in de ervaring dat alles in de sterren geschreven staat en sinds het begin der tijden onherroepelijk vaststaat? Waarheen leidt ons een denken van de contingentie, tenzij naar de ervaring dat de betrekkelijkheid ons bestaan openscheurt en dat elke zingeving die zich als absoluut voordoet, vals is? Misschien is God niets tenzij deze scheur die niet is... 
Terwijl de scheppingsleer het niets vergeet, loochent de leer van de triniteit het gevaar van verlies door elke mogelijke verdubbeling uit te schakelen. Dankzij deze uitschakeling van elk verlies kan de triniteit zich presenteren als een volmaakt onaantastbare cirkel. Immers, enerzijds heeft God nood an een veruiterlijkende verwoording, aan het vlees geworden woord, anderzijds doet deze belichaming geenszins afbreuk aan de absolute identiteit van God. De onaantastbare eenheid van de drievuldigheid zorgt ervoor dat God de Vader onverdeeld bij zichzelf aanwezig blijft in de verwoording van zichzelf. In absolute identiteit met zichzelf schenkt God (de Heilige Geest) zichzelf (de Zoon en het Woord) aan zichzelf (de Vader) terug. Zowel het lichaam als het woord keren restloos naar de vader terug: zoals elk mogelijk verlies wordt gerecupereerd, zo worden elke vorm van temporalisering (of vertijdelijking) en van verruimtelijking uitgewist.

Heideggers uitspraak "Alleen een god kan ons redden" willen we tegen deze achtergrond lezen en interpreteren. Zijn hele denken is een uiteenzetting met het nihilisme en als zodanig een poging om het niets niet uit te schakelen, maar om de onvatbaarheid en ondraaglijkheid ervan te doorstaan. De redding waarover sprake, betreft dan ook zonder meer het nihilisme: alleen een god kan ons redden van het nihilisme.

Daartoe is allereerst een andere antropologie vereist. De traditionele filosofie vat de mens op als een animal rationale, als een met rede begiftigd levend wezen. Hoewel Heidegger vele vragen heeft bij wat het betekent 'rationeel' te zijn en er voortdurend op wijst dat de rationaliteit waarop het westen zich beroept, een erg beperkte en verminkte vorm van spiritualiteit of van denken is, bekritiseert hij ook de opvatting dat de mens een levend wezen is. Als een rode draad door al zijn geschriften heen loopt de gedachte dat de mens existeert, dat wil zeggen een sterveling is. Maar zoals Heidegger eveneens altijd opnieuw laat zien, behoort tot de zijnsconstitutie van de sterveling het nauwelijks te doorgronden feit dat hij uitgerekend het sterven, dat nochtans zijn oninneembare eigenheid uitmaakt, vergeet, veronachtzaamt en verwaarloost. Dat we sterfelijk zijn, willen we liever niet geweten hebben, en veel van onze werkzaamheden zijn er precies op gericht om niet deelgenoot van deze ervaring te worden. Deze vergetelheid wordt nog in de hand gewerkt door de westerse metafysica, die de dood schrapt uit de definitie van de mens, en door het christendom, dat met het gebod "Gedenk dat gij stof en as zijt" niet aanzet tot een inachtname van het sterfelijke, maar op een overwinning ervan aast. 
Heidegger brengt dit ter sprake in een uitgebreide commentaar op een vers van Georg Trakl. Dit vers luidt als volgt: "Es ist die Seele ein Fremdes auf Erden". Zonder enige moeite kan men dit lezen als een variant op psalm 119, waarin staat: "Ik ben een vreemdeling op aarde." Heideggers lectuur breekt echter onmiddellijk en zonder voorbehoud met elke platoons-christelijke interpretatie van dit vers die een beroep zou doen op het al te bekende schema sôma/sêma. Het gaat hier volgens hem niet om de vreemdheid van de eeuwige ziel die verbannen is naar een verblijf op aarde temidden van vergankelijke schaduwen; evenmin in het geding is een oproep aan de ziel om haar ballingschap te beëindigen en zich tot haar ware vaderland in het hiernamaals te wenden. Integendeel, precies tegen een dergelijke vlucht van de ziel is Heidegger gekant. Hij schrijft dan ook: "Die Seele sucht die Erde erst, flieht sie nicht." De vreemdheid van de ziel leidt niet tot een vlucht, maar veeleer tot een zoektocht. Deze zoektocht is niets minder dan een poging om de aarde als aarde te redden: wat de ziel op aarde zoekt, is de aarde, de vreemdheid van de aarde, en de vreemdheid van zichzelf. De ziel die trouw is aan haar bestemming, streeft er dus niet naar om de vreemdheid die haar lot is, op te heffen, zoals de platoonschristelijke traditie het wil, maar om de vreemdheid van het vreemde te onthullen, om het vreemde als bestemming te aanvaarden.

Wie deze opgave op zich neemt, is het gegund om, zoals Heidegger zegt, de aarde als aarde te redden. Dit betekent dat de mens afstand doet van de minstens sinds Descartes geldende drang om "maitre et possesseur de la nature" te worden, om de aarde technisch en economisch uit te buiten en industrieel te verwoesten. Veel meer dan een verdoken oproep om anders te gaan leven of om lid van Greenpeace te worden, staat hier een houding op het spel die het geheim van de aarde respecteert. Niets is voor de westerse mens in de loop van zijn geschiedenis onverdraaglijker gebleken dan de geheimzinnige stilte van de aarde en de ontoegankelijkheid van de stof. Met niets ontziend geweld heeft de westerse mens het stoffelijke gedwongen om te spreken, om zijn geheimen prijs te geven, en de aarde opgevorderd om teken te zijn. Dit is het geval bij waarzeggers die voor- of tegenspoed aflazen aan de vlucht en het geschreeuw van vogels, bij alchemisten die geneeskunde bedreven op basis van een analogie tussen kruiden en het menselijk lichaam (noten zijn gezond voor de hersenen aangezien...), bij phrenologen die misdadigers herkennen aan de vorm van hun schedel, maar ook bij ontspoorde eugenetici die de fysieke, psychische en ethische geaardheid van een individu afleiden uit zijn genetische constellatie. Wat is dit tenzij het aloude geloof dat niets gebeurt zonder reden of oorzaak, dat God de auteur is van het boek der schepping en dus elke letter in betekenis kan omzetten? De aarde redden is de smart aanvaarden dat er niet gesproken wordt, dat het zwijgen heerst; het is, zoals Nietzsche in Morgenröte te verstaan geeft, het menselijk al te menselijk verlangen laten varen dat de verheven stilte van de aarde iets zou verbergen. Wie verzaakt aan dit verlangen, beseft dat het geheim 
van de aarde niet draait om verstopte en dus te decoderen boodschappen, maar dat het de eindeloze dissimulatie is van een afgrondelijke contingentie.

Het geheim van de contingentie maakt de wet van het sterveling-zijn uit. Heidegger brengt dit ter sprake in een etymologie die tot een krachtig evocatief beeld uitgewerkt wordt. Het menselijk geslacht is sterfelijk, omdat het geslagen is en vervloekt. Heidegger zinspeelt hier op een dubbele etymologie: het woord 'Geschlecht' (in het Nederlands 'geslacht') is verwant met 'geschlagen' en het woord 'Fluch' (in het Nederlands 'vloek') betekent oorspronkelijk zoiets als 'Schlag'. Het menselijk geslacht is geslagen, omdat het uit elkaar geslagen is in een tweedracht; de mens is vervloekt door een weerspannige verhouding met de eigen sekse, de eigen familie, het eigen volk, het eigen ras. Door deze vloek is de mens een vreemde op aarde en is hij vaak van slag af. Toch is de mens niets tenzij deze slag die hem typeert en stempelt tot wat of wie hij is. Daarom komt het er voor de mens niet op aan om zich van deze vloek te bevrijden, maar wel om enigermate de juiste slag te vinden en zich naar deze vloek te schikken.

Heideggers bedenkingen rond het geslacht leunen ongetwijfeld aan bij Lacans theorie van de castratie. De geslachtelijkheid castreert de mens, dat wil zeggen verbant hem in een lichaam dat hem nooit zal toebehoren. De opdracht van het sterveling zijn die Lacan met de woorden van Sophocles omschrijft als "mê phunai" of als de vloek om geboren te zijn en een lichaam te hebben, bestaat erin zich aan de wet van de castratie te onderwerpen en de vloek te dragen als een naam en een door de vader gedane belofte.

Dit alles vertelt ons een en ander over de redding die Heidegger op het oog heeft. Die redding ligt, ten eerste, in een waarachtig materialisme. Geïnspireerd door een lange metafysische traditie, heeft de westerse cultuur zich altijd van het materiële afgewend en het herleid tot bewerkbare stof. De metafysica heeft het stoffelijke geofferd door het ten dienste te stellen van een technische manipulatie of door het op te vatten als de doorzichtige matrix van een idee. Daarom is het stoffelijke altijd verschenen als mogelijke energie of als te decoderen boodschap. Een van de grootste misverstanden omtrent 'de hedendaagse technologische cultuur zegt dan ook dat we in een materialistisch tijdperk leven. In feite is de hedendaagse cultuur van alles verslindende technologie en consumptie doordrongen van een verminkend spiritualisme dat er op gebrand is de ontoegankelijkheid en ondoorgrondelijkheid van het stoffelijke uit te wissen: dit spiritualisme zoekt naar het nut, de toepasbaarheid en berekenbaarheid van het materiële en heeft elke voeling verloren met wat Heidegger noemt: "die Erde als das wesenhaft Sichverschliessende". 
Ten tweede, precies omdat de aarde (of het stoffelijke en het zinnelijke) zich verhult, blijft elke houding die afziet van een bewerking of een conceptualisering, een hachelijke onderneming. Het materialisme dat Heidegger voorstaat, kan er niet op bogen het wezen van de aarde ontsluierd te hebben of zich op een eigenlijke manier tot het geheim van het stoffelijke te verhouden. Precies dat verlangen wordt door Heidegger ontmaskerd in het volle besef dat het onuitroeibaar is en dat het ermee samenhangende nihilisme onoverwinnelijk is. Toch gaat het bij Heidegger om een soort bereidheid de onpeilbaarheid van het stoffelijke toe te laten, dat wil zeggen om een ontvankelijkheid voor de grenzen van het mogelijke, om de gelatenheid het onmogelijke niet te beschouwen als een te overwinnen obstakel.

Ten derde, de redding die Heidegger verwacht, verlost de mens dus helemaal niet van zijn aardse of existentiële tekorten en neemt zeker niet de zonden uit de wereld weg. Integendeel, ze bestaat in de opgave om deze tekorten te gedenken en als nood te aanvaarden. De mens heeft nood aan een redding, omdat hij altijd opnieuw de nihilistische waan koestert boven elke nood verheven te zijn. Daarin schuilt het gevaar van de technologie, zoals Heidegger nog in het gesprek met Der Spiegel herhaalt: een wereld waarin alles functioneert of waarin het principiële geloof heerst dat men alles kan doen functioneren, is een verschrikking; anders gezegd: het grootste gevaar bestaat erin te geloven aan elk gevaar ontheven te zijn en geen redding te behoeven.

Binnen diezelfde logica van de eindigheidsfilosofie geldt ook het principe dat de mens zichzelf niet kan redden. Niets is voor Heidegger onzinniger dan de humanistische overtuiging dat de mens voor zichzelf kan instaan, dat de menselijke 'perfectibiliteit' de drijvende kracht van de geschiedenis uitmaakt en dus ook voor de mens als soortelijk wezen het hoogst te bereiken doel vormt. Precies omdat de mens existeert als sterveling, hoort hij niet toe aan zichzelf en is hij geworpen in een existentie die door een voor immer onkenbaar, vaak ondraaglijk 'buiten' gestempeld is. De sterveling stoot in zichzelf op de onherbergzame vreemdheid van zichzelf en ontdekt dat die vreemdheid helemaal niet tegenst:ijdig is met, maar vaak de averechtse uitkomst is van een al te innige verknochtheid aan wat die existentie in een en dezelfde beweging regelt en ontregelt. Om de ontwrichtende logica van de eindigheid te doorstaan in een lijdzaamheid die zeker niet met futloosheid verward mag worden, heeft de mens nood aan wat hij zichzelf niet kan schenken en aan wat de uitzichtloze geslotenheid van de zelfredzaamheid doorbreekt. 
De gelatenheid om als sterveling te existeren, de ontvankelijkheid voor het geheim van de aarde, de moed om de nood te erkennen zijn sporen naar God of het goddelijke. Immers, deze god of dit goddelijke komen ons tegemoet, als we vertrouwd raken met wat Heidegger noemt: "die Verweigerung". Wat wordt bedoeld met dit woord, dat opduikt in het slechts postuum gepubliceerde manuscript Beiträge zur Philosophie, dat Heidegger -naar verluidt- als zijn tweede hoofdwerk beschouwde?

Ten eerste, wie deze god ook mag zijn, hij zal het tekort niet ongedaan maken. Hij zal geen rijk stichten van volledig zaligmakende volmaaktheid. De ontotheologische speculaties over de eeuwigheid, de eenheid en onvoorwaardelijke aanwezigheid van God zijn door Heidegger ontmaskerd als ingegeven door nihilistische berekeningen.

Ten tweede, een religieus reveil is uit den boze. Zowel de god der filosofen en der theologen als de god van Abraham en Jezus of de Griekse goden waarover mythen en tragedies verhalen, blijven ons, postmodernen, ontzegd. Heidegger is het wat dat betreft helemaal eens met Hölderlin, die in de ode Germanien dicht:

Nicht sie, die Seeligen, die erschienen sind,

Die Götterbilder in dem alten Lande,

Sie darf ich ja nicht rufen mehr...

(Die niet, de zaligen die eens verschenen, gestalten van de goden in het oude land, die mag ik niet meer roepen...)

Heidegger heeft zich enorm ingezet om recht te doen aan de Griekse eredienst van Apollo en Dionysus, van Artemis en Hestia, en om de verhalen over de Schikgodinnen en de tragische helden niet als flauwe verzinsels van de hand te wijzen. Hij heeft het dédain verfoeid dat żelfs hellenofielen ertoe brengt om deze goden als verpersoonlijkingen te zien en om het joodse geloof in Jahweh als superieur te beschouwen in vergelijking met de Griekse riten. Toch is hij zich te veel bewust van de historische situatie om een terugkeer te preken. De afstand tussen het Griekenland van Homerus en van Sophocles en het Europa van internet en soap-opera's is te groot. Het is uitgerekend zijn intense liefde voor de Griekse goden die hem verbiedt hen terug te roepen of hun eredienst te herstellen. Met de woorden van Hölderlin:

Und rückwärts soll die Seele mir nicht fliehn

Zu euch, Vergangene! die zu lieb mir sind.

[...] tödtlich ists

Und kaum erlaubt, Gestorbene zu wecken. 
(Nu mag mijn ziel niet meer terug naar jullie, schimmen die vergingen en waar ik te veel van hou.

[...] levensgevaarlijk is het, nauwelijks geoorloofd doden op te wekken.)

Het is met de Griekse goden zoals met de doden: we moeten afscheid van hen nemen. Onze liefde verplicht ons juist om hen te laten gaan, om hen te laten vergaan en verlijden. Het is ons niet geoorloofd om ons krampachtig aan hen vast te klampen. We zien ons geplaatst voor de zware opgave van de rouw: een aandenken bewaren aan wie geweest is in de deemoedige erkenning dat dit aandenken op geen enkele manier het verleden terugbrengt of de dode doet herleven.

Ten derde, in zijn lectuur der overleverde verhalen wijst Heidegger ook op het monsterlijke dat in de antieke eredienst huist. Hij waarschuwt met Hölderlin voor het hevige verlangen dat in de religie woedt, voor het enthousiasme dat de mens met God vervult of waardoor hij door God bezeten wordt. Wie huivert niet bij het verhaal van Semele, die verast werd omdat ze zich met Zeus wou verenigen, of bij het verhaal van Abraham, die klaar stond om zijn zoon te offeren? Wanneer Heidegger over 'die Verweigerung' spreekt, dan suggereert hij ongetwijfeld dat wij niet langer Gods wil kennen en dat de opdracht om Gods wil uit te voeren ons dan ook bespaard is. Met Slavoj Zizek kunnen we inderdaad bevestigen dat wie het verlies van de primitieve verhouding tot het goddelijke betreurt in onze utilitaire samenleving, niet het recht heeft om verontwaardigd te zijn over de nazi-misdaden. "Gottes.Fehl hilft" schrijft Hölderlin op een moment dat hij volgens sommigen al waanzinnig geworden is: het uitblijven van God is een hulp. Hoe vreemd het ook mag klinken, niets is blijkbaar voor de mens ondraaglijker dan de gedachte dat hij niet opgenomen is in een groot plan, dat hij geen deel uitmaakt van een kosmisch lot. Het behoort tot ons lot om bevrijd te zijn van elke lotsbestemming, maar blijkbaar ervaren we die vrijheid eerder als een roof, ervaren we die doelloosheid als een armoede of een ramp.

Nochtans houdt de nederigheid die ons verlost van de gedrevenheid om Gods wil uit te voeren, een onschatbaar geschenk in. Ze ontdoet ons namelijk van het apocalyptisch verlangen dat de menselijke activiteiten stuurt. Een definitieve oplossing, een definitieve overwinning op het kwaad is de mens niet gegund. Handelen in Gods naam kan dan hoogstens betekenen dat het definitieve wordt opgeschort, dat het verleden niet wordt afgesloten en de toekomst gevrijwaard blijft. Wie handelt in Gods naam, verzaakt aan de terreur van het 'nu of nooit', weet dat de wanhoop en het afgrendelen van de toekomst de wereld overlevert aan de helse herhaling van het eendere en dat de mens de hoop geschonken is omdat het leven zo hopeloos lijkt. De ervaring van 'die Verweigerung' leert de hartsgrondige ontstentenis die de we- 
reld merkt. Sterveling zijn houdt in die ontstentenis doorstaan in het besef dat alleen waar het allerergste niet uitgesloten wordt, een zinvolle existentie mogelijk blijft.

Met Hölderlin onderneemt Heidegger dus een bezinning over wat het betekent abendländisch te zijn, dat wil zeggen te leven in het Avondland, in een cultuur die afloopt en misschien een nieuw tijdperk voorbereidt. Hij constateert dat het eigene van dit zijnsbestel schuilt in een weigering: God heeft zich teruggetrokken en deze terugtrekking laat ons verweesd achter. We weten nauwelijks waar we aan toe zijn, ondanks de bergen informatie waarover we beschikken, ondanks de enorme kennis die we dagelijks opslaan. De bloei van wetenschappen en technologie vertelt ons weinig over wie we zijn, wat het betekent te existeren als sterveling, hoe ons te verhouden tot onze naaste, tot de wereld of tot de aarde. We zien alleen dat de kloof tussen wat we kennen en kunnen enerzijds en wat we met die 'know how' weten aan te vangen anderzijds kolossale afmetingen begint aan te nemen. Het meesterschap der cijfers gekoppeld aan de radeloosheid omtrent de maat van ons bestaan: dat is de ontnuchterende eigenheid van de postmoderne mens.

Die eigenheid verwerven is de vreemde opdracht die ons gegeven is. Niets, zegt Hölderlin, is moeilijker dan het vrije gebruik van het eigene: niets is moeilijker dus dan een omgang met de weigering, met de aftocht van God, met het ontbreken van een lot, met de vertrouwdheid met cijfers. Het meest nabije is vaak het meest onbereikbare: op dezelfde manier vindt de mens uit het technologische tijdperk het onbegrijpelijk lastig om zich de mathematisering en formalisering die hem aangeboren lijken, waarachtig toe te eigenen. In dat verband wijst Heidegger op de eenstemmigheid van de hedendaagse cultuur. Deze eenstemmigheid is een pijnlijk tekort: ze onderwerpt ons immers genadeloos aan de eisen van de technologie. Ze staat voor de onmiddellijke aanspraak die de technologie op de postmoderne mens maakt. Een onmiddellijke aanspraak, dat wil zeggen een aanspraak zonder bemiddeling én een aanspraak die ons aan de onmiddellijkheid overlevert: onmiddellijke acties, onmiddellijke consumptie, onmiddellijke resultaten. Afstand nemen ten aanzien van de technologie houdt voor Heidegger zonder meer in dat die onmiddellijkheid gebroken wordt, dat de eenstemmigheid ontstemd wordt en dat wij, postmodernen, ook gevoelig worden voor andere stemmen, voor de anspraak die zich in de weigering hult.

Zo zijn we misdeeld door het lot: we zijn niet getroffen door een ondraaglijk lijden; integendeel, ons ontbreekt precies het vermogen om ondraaglijk te lijden, meer nog het vermogen om dit gebrek aan ondraaglijk lijden in zinvolheid om te zetten. We zijn ramptoeristen geworden, die zich bij voorkeur ophouden op plaatsen waar het spektakel van de catastrofe kan worden aanschouwd en geproefd. Van een 
catharsis is al lang geen sprake meer, hoogstens van oververzadiging: de toestand bij uitstek van wie zich aan overconsumptie te buiten gegaan is.

Het is zonder enige twijfel van ongemeen belang om het kannibalisme van het consumptietijdperk af te leren. Ook al blijft een catharsis ons ontzegd, al was het maar omdat we nooit alleen maar toeschouwer kunnen zijn. Zoals Hölderlin in een brief aan een jeugdvriend schrijft, het tragische bij ons is dat we stil en verpakt in een kist verdwijnen van het rijk der levenden, terwijl de antieke held in vlammen boette, omdat hij het vuur in hemzelf niet wist te bedwingen. Toch mogen we niet terugverlangen naar die bevlogenheid, maar moeten we in die nuchterheid een existentie uitbouwen en zeggen: à-dieu, vaarwel aan God.

Dit afscheid breekt het verlangen naar het bovenaardse af en verpandt de sterveling aan het aardse en het tijdelijke. Daar krijgen we de enorme zorg toegewezen voor wat leeft en sterft, voor wat uit het verleden op ons toekomt, voor de broosheid van wat niet meer is dan een letter of een datum.

Ik heb in het voorgaande meermaals beklemtoond dat Heidegger zijn bezinningen over God en het goddelijke ontwikkelt na een ontmanteling van de christelijke traditie. Vanuit de ervaring van 'die Verweigerung' poogt Heidegger een ander denken over God op gang te brengen. Hij noemt deze god: "der ganz Andere gegen die Gewesenen, zumal gegen den christlichen". Toch rijst de vraag in hoeverre Heideggers onderneming strijdig blijft met enige binnen het christendom verwoorde inzichten of ervaringen.

Heideggers overtuiging dat de mens vaarwel dient te zeggen aan God, vinden we terug bij de Duitse mysticus Eckhart. In diens sermoen 'Beati pauperi' staat: "Ich bitte Gott dass er mich quitt mache Gottes." Ook Eckhart zoekt naar een verlangen dat er niet langer op gericht is Gods wil te vervullen. De trouw aan dat verlangen, dat zich in een soort van heilig verraad van God afwendt, is volgens Eckhart een noodzakelijke voorwaarde om rechtvaardig te handelen. De rechtvaardige wordt immers geacht te handelen in naam van het rechtvaardige, niet om tegemoet te komen aan God. Alleen wie erin slaagt God los te laten, is het gegund om de gelatenheid te verwerven of de armoede van geest die volgens Eckhart de toegangspoort naar het rijk Gods opent.

De schreeuw van de gekruisigde - "Mijn God, mijn God, waarom hebt gij mij verlaten?" - getuigt van een zelfde verlatenheid. Al te vaak wordt deze schreeuw geduid als de jammerlijke, maar begrijpelijke zwakte van de stervende die in zijn laatste uur God aanroept en niet weet dat God bij hem is. Maar wat als deze schreeuw God nooit bereikt en uiting geeft aan de onherroepelijke eenzaamheid van het lijden dat verdwijnt in de plooien van een onzinnige geschiedenis? Misschien 
blijkt uit deze schreeuw dat God sterft in de gekruisigde Jezus en dat deze dood een onherstelbaar verlies is. Of dat noch Jezus noch zijn woorden de weg naar God terugvinden. Misschien geeft deze schreeuw te kennen dat de geest gedacht moet worden als de breuk tussen de vader en de zoon, als de onoplosbare spanning tussen de onkenbaarheid van de hemel en de vergeefsheid van de aarde. Maar ook dat de geest niets is tenzij de voor immer onzekere toedracht dat de aarde betekent.

Binnen een op die manier begrepen spiritualiteit gaan vele geboden uit het christendom er radicaal anders uitzien. Ik denk hier met name aan het gebod van gehoorzaamheid, dankbaarheid, herinnering en trouw dat het christendom onmiskenbaar structureert. Als de geest precies existeert doordat hij de weg naar de oorsprong niet terugvindt, kan het danken nooit voltrokken worden door een teruggave of restitutie. Danken houdt dan geen eerbetuiging in van de gave of van de gever, maar onthult het geheim van het geven dat zich in een nauwelijks ontwarbare vervlechting van vrijheid en wetmatigheid als vrij-gevigheid ontplooit. Waarachtig danken kan dan de vorm aannemen van een vergetelheid die amper van ondankbaarheid te onderscheiden is. Niemand heeft dit beter begrepen dan Nietzsche, die als geen ander het christendom geparodieerd heeft. Zijn ultieme wens, neergepend in de meedogenloze dagen van januari 1889, luidt: "Ik beveel u mij kwijt te spelen..." Het spreekt vanzelf dat de onuitvoerbaarheid van dit bevel onpeilbaar is.

Moeten we hieruit besluiten dat het christendom één van de vele gestalten is die de vraag naar God kan aannemen? Dat we toe zijn aan een ontmanteling van het christendom, aan een hernieuwde lectuur van de bijbelse en evangelische traditie? Hoe dan ook, we kunnen het gesprek met de geest niet afsluiten, zeker niet het gesprek met de geest (en het spook) van het christendom, tenzij we de rol accepteren van de Grootinquisiteur, zoals beschreven in De gebroeders Karamazov van Dostojevski. Dit verhaal, waarin één van de karakters ten onrechte opmerkt dat na de dood van God alles toegestaan is, voert Jezus op, die na vele eeuwen de aarde opnieuw bezoekt en slechts door de Grootinquisiteur herkend wordt. Die laat Jezus in de gevangenis opsluiten en bijt hem de volgende woorden toe: "Waarom bent $u$ ons komen hinderen? Maar weet $\mathrm{u}$ wat er morgen gebeuren gaat? Morgen zal ik $\mathrm{u}$ tot de brandstapel veroordelen en laten verbranden als de ergste ketter en datzelfde volk dat vandaag uw voeten gekust heeft zal morgen op mijn geringste handgebaar komen toesnellen om houtskool aan te dragen voor uw mutsaard, weet u dat?" En hij voegt er met dogmatische zelfverzekerdheid aan toe: "U hebt het recht niet om nog iets toe te voegen aan uw woorden van vroeger." Dogmatici menen toegang te hebben tot de waarheid die ze als een testament beheren. Maar beschikken we wel over een testament, oud of nieuw? Moeten we wat ons nagelaten is niet lezen als een getuigenis, als een bekentenis, waarvan de betekenis slechts vergeleken kan worden met de eenzaamheid van een wonde? Zijn we niet overgeleverd aan het onherbergzame appel "Volg mij"? Wat is dit tenzij een oproep tot bekering of, om met Hei- 
degger te spreken, tot ommekeer? Een dergelijke oproep berooft ons van alle testamentaire zekerheden die ons vertellen welke bezittingen uit het verleden ons toebehoren. Hier klinkt de uitnodiging om het niet-identieke te omhelzen of, anders gezegd, om radicaal tijdelijk te zijn. Deze uitnodiging vertrouwt ons de bereidheid toe om opnieuw te beginnen en te vertrekken.

"Alleen een god kan ons redden" - in het licht van het voorgaande zou ik het woord "alleen" willen schrappen. Onze redding wordt misschien gedragen door de naam van God, indien die ons het verlangen naar het absolute ontzegt en ons begeleidt naar de nietigheid van het aardse door ons in te schrijven in de ongerijmdheid van een eindige, ontwrichte tijd. Zoals andere namen en woorden waarvan we de betekenis nauwelijks kennen, zoals data die ons hart bezetten, houdt de naam van God de belofte open van een onvoorstelbare en onvoorspelbare toekomst en bewaart hij het aandenken aan een nimmer verwerkt, altijd verloochend verleden. Wat er dan van het heden rest, weet ik niet. Het zij zo.

\section{Literatuur}

J. Derrida, De l'esprit: Heidegger et la question. Parijs, Galilée, 1987.

M. Heidegger, Vorträge und Aufsätze.Pfullingen, G. Neske, 1978 (4).

- , Unterwegs zur Sprache. Pfullingen, G. Neske, 1982 (6).

- , Der Europäische Nihilismus. Pfullingen, G. Neske, 1967.

- , Hölderlins Hymnen "Germanien" und "Der Rhein", (GA 39), (Hsgb. S. Ziegler). Frankfurt, V. Klostermann, 1980.

- , Beiträge zur Philosophie, (GA 65), (Hsgb. F.W. von Herrmann). Frankfurt, V.

Klostermann, 1989.

F. Hölderlin, Werke und Briefe. Frankfurt, Insel, 1983.

J. Lacan, L'éthique de la psychanalyse. Paris, Seuil, 1986.

F. Nietzsche, Werke., (Hsgb. K. Schlechta). Berlin, Ullstein, 1969.

S. Zizek, Het subject en zijn onbehagen. Amsterdam, Boom, 1997. 